Egyptian Poultry Science Journal

http://www.epsaegypt.com

ISSN: 1110-5623 (Print) - 2090-0570 (Online)

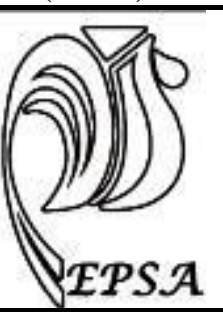

\title{
EFFECT OF USIN GCANOLA MEAL TREATED BY CLAY ON LAYING HEN PERFORMANCE UNDER DESERT CONDITION Said E. M. El-Sheikh
}

\author{
Dep. of Anim. and Poult. Nut., Desert Res. Center, Mataria, Cairo, Egypt.
}

Corresponding author: Said E. M. El-Sheikh; Email: saidelsheikh@yahoo.com

\begin{abstract}
Received:03/04/2017
Accepted:19/04/2017

ABSTRACT: A total number of 105 Lohman laying hens, 22 weeks of age were used to study the effect of using canola meal treated by clay on laying hen performance under desert condition. Hens were divided equally into seven treatment groups; three levels of CM (10, 15 and $20 \%)$ and two levels of clay ( 0 and $2 \%$ ), in addition to control group. Each group contains five replicates with 3 birds each.

Canola meal had a moderate levels of most amino acids but higher levels of methionine and arginine (1.50 and $30.21 \mathrm{mg} / \mathrm{g}$ ) compared to amino acid of Soya bean meal (1.05 and 25.85 $\mathrm{mg} / \mathrm{g}$ ). Hens fed $20 \% \mathrm{CM}$ with or without $2 \%$ clay recorded the lowest significant final body weight and body weight change (1589.00, 1593.33 and 69.33, 74.00 g), respectively. Hen fed $15 \% \mathrm{CM}$ with $2 \%$ clay recorded higher egg production and egg mas $(81.54 \%$ and 46.72 $\mathrm{g} /$ hen/day). Hens fed 20\% CM without clay recorded the highest feed consumption value (111.6 $\mathrm{g} /$ hen/day). While, the control group recorded the best feed conversion ratio $(2.39 \mathrm{~g} \mathrm{feed} / \mathrm{g} \mathrm{egg}$ ) followed by the group fed $15 \%$ with $2 \%$ clay $(2.61 \mathrm{~g}$ feed $/ \mathrm{g} \mathrm{egg})$. Hens fed diet containing $15 \%$ $\mathrm{CM}$ with $2 \%$ clay recorded the highest relative weight of yolk $(22.01 \%)$. However hens fed $20 \%$ CM with $2 \%$ clay recorded the lowest value of yolk index $(45.99 \%)$ and yolk color (7.80). Alanine transaminase (ALT) was increased significantly in hens fed $20 \%$ without or with $2 \%$ clay (41.00 and 39.33 I.U.L.). While, ALT was decreased $(\mathrm{p} \leq 0.05)$ in hens fed 10 and $15 \%$ CM with $2 \%$ clay (24.33 and 25.00 I.U.L.). The results indicated that $15 \% \mathrm{CM}$ with $2 \%$ clay in laying hen diets improved significantly egg production, egg mass, egg quality, digestion coefficients, blood characteristics, economic efficiency and relative economic efficiency under desert condition.
\end{abstract}

Key words:Canola meal-Egg quality-Digestion coefficients- Blood characteristics -Clay. 


\section{INTRODUCTION}

It is now urgent to look for unconventional feedstuffs such as agro- industrial by-products to compensate the high cost of the conventional ones. Canola meal $(\mathrm{CM})$ could be considered as a cheaper by-product and could successfully substitute soya ben meal in poultry diets as source of protein in poultry feeding. Crud protein of canola meal represented $34.93 \%$ (El-Sheikh, 2016). The higher level of $\mathrm{CM}$ up to $10 \%$ in poultry rations showed a negative effect on poultry performance. The negative effects may be due to the anti-nutritional factors such as tannins (Thanaseelaan et al., 2007), which presented 1.5\% (Newkirk et al., 2003a). Tannins are water soluble phenolic compounds with a molecular weight greater than 500 and with the ability to precipitate protein form aqueous solution. They occur almost in all vascular plants. Hydrolysable tannins (500-3000DaTannic acid) and condensed tannins (100020000Da-proanthocyanidins) are two different groups of these compounds (Frutos et al., 2004).

Dietary tannins inhibit the intestinal uptake and transport of simple sugars, amino acids and minerals (King et al., 2000; Song et al., 2002; Afsan et al., 2003; Johnston et al., 2005; Kim and Miller, 2005). Some additives may counteract some of these problems, for example clay are uptake tannins intake, allowing dietary ingredients to be digested and utilized more efficiently. A number of studies carried out in using clay in laying hen diet (Jin Soo Kim et al., 2011) reported that there were linear deceased in feed intake $(\mathrm{p} \leq 0.01)$ with increasing dietary clay level $(0.0,0.2$ and $0.4 \%)$, improvement in FCR $((\mathrm{p} \leq 0.05)$ and egg production. Kermanshahi et al. (2011) found that egg production, egg weight, shell thickness and shell percent values were not significantly affected by clay levels $(0.0,1.5$ and $3 \%)$. The objective of this work was to study effect of using canola meal treated by clay on egg production and egg quality of laying hen under desert condition.

\section{MATERIALS AND METHODS}

A total number of 105 Lohman laying hens, 22 weeks of age were used to study effect of using canola meal treated by clay on laying hen performance under desert condition. The present study was carried out at Siwa Oasis Research Station belonging to Desert Research Center (DRC), Egypt. Birds were divided equally into seven treatment groups' three levels of $\mathrm{CM}(10,15$ and $20 \%)$ and two levels of clay ( 0 and $2 \%$ ), in addition to control group. Each group contains five replicates with 3 birds each. Clay was mixed with canola meal then it mix with ingredients. The experimental diets (Table 1) were formulated to be iso-caloric $(\sim 2800 \mathrm{Kcal} \mathrm{ME}$ $/ \mathrm{kg}$ diet) and iso-nitrogenous ( $18.00 \% \mathrm{CP})$ to meet recommendations for Lohman laying hens. The birds were housed in wire cages of triple deck batteries. The hens were exposed to $15 \mathrm{~h}$ light /day during the experiment. Feed and water were provided ad libitum. Body weights were recorded at the beginning of the experiment ( 22 weeks of age) and at the end of the experiment (34 weeks of age). Clay contained $1.5-2.25 \% \quad \mathrm{Na}_{2} \mathrm{O}, 2.5-3.5 \%$ $\mathrm{MgO}, 23-25 \% \mathrm{Al}_{2} \mathrm{O}_{3}, 45-56 \% \mathrm{SiO}_{2}, 0,5-$ $0.9 \% \mathrm{~K}_{2} \mathrm{O}, 1.8-2.5 \% \mathrm{CaO}, 6-8 \% \mathrm{Fe}_{2} \mathrm{O}_{3}$, and $1-1.25 \% \mathrm{TiO}_{2}$.

Body weight changes were calculated as the difference between the initial and final body weight. Egg weight and egg number were recorded daily to calculate the egg mass ( $\mathrm{g} / \mathrm{hen} /$ day). Feed consumption was recorded biweekly, while feed conversion value ( $\mathrm{g}$ feed /g eggs) were calculated as the amount of feed consumed divided by egg mass. Chemical analysis was carried out in the laboratories of the Animal and Poultry Production Department, Desert Research Center. At the end of the experiment treatment, three meals 


\section{Canola meal-Egg quality-Digestion coefficients- Blood characteristics -Clay.}

from each treatment groups were used and housed individually in metabolic cages to carry out digestibility trials in order to calculate nutrients digestibility coefficients. Feed intake and output of excreta were recorded for 3 days. Samples dried excreta and diets were used to chemical analyze dry matter, crude protein, crude fiber, ether extract, ash and fiber fraction according to A.O.A.C. (1990). The procedure of Jakobsen et al. (1960) was followed to determine the faecal nitrogen. Urinary organic matter was calculated according to Abou-Raya and Galal (1971).

Egg quality parameters were measured using 35 eggs ( 5 eggs / each treatment group). These involved yolk, albumen and shell weight percentage. Egg shell thickness was measured in mm using a micrometer. Egg shape index was calculated according to Romanoff and Romanoff (1949) as an egg diameter divided by an egg length. Yolk index was calculated according to Funk et al. (1958), as yolk height divided by yolk diameter. Haugh unit was calculated according to Eisen et al. (1962) using the calculation chart for rapid conversion of egg weight and albumen height. Yolk color was determined with a commercially available "yolk color fan" according to the CIE standard colorimetric system (Yolk Colour Fan, the CIE standard colorimetric system, F. Hoffman-La Roche Ltd., Basal, Switzerland). Amino acid concentrations in canola meal and soya bean meal were determined according to Pellet and Young (1980).

At the end of the experiment, three blood samples from each treatment were withdrawn in test tubes, put horizontal for ten minutes to clot and centrifuged at $3000 \mathrm{rpm}$ for 15 minutes to get or collect the serum, and preserved in deep freezer at $-18^{\circ} \mathrm{C}$ until the time of analysis. Serum total protein and albumin, total lipid, urea, creatinine, alanine transaminase (ALT) and aspartate transaminase (AST) were determined by the colorimetric methods with commercial kits. Serum globulin was calculated by subtracting serum albumin from serum total protein.

Economic efficiency of egg production was calculated from the input-output analysis which was calculated according to the price of the experimental diets and eggs production during the year of 2014. The values of economic efficiency were calculated as the net revenue per unit of total cost.

\section{Statistical Analysis:}

Data were analyzed by the Computer Program, SAS (2003), using the General Linear Model (GLM) procedure. All the characteristics were performed in conformity by factorial analysis and one way analysis model. The significant differences among treatments means were separated by Duncan's Multiple Range-Test (Duncan, 1955).

Model applied was:

a- factorial analysis

$Y_{i j k}=\mu+X_{i}+Z_{j}+(X Z)_{i j}+e_{i j k}$

Where: $Y_{\mathrm{ijk}}=$ observation, $\mu=$ overall mean, $\mathrm{X}_{\mathrm{i}}=$ canola meal effect, $\mathrm{Z}_{\mathrm{j}}=$ clay effect, $(\mathrm{X}$ $\mathrm{Z})_{\mathrm{ij}}=$ interaction between canola meal and clay level, $\mathrm{e}_{\mathrm{ijk}}=$ experimental errors.

b- one way analysis

$Y_{i j}=\mu+T_{i}+e_{i j}$

Where: $Y_{i j}=$ Observed value of a given dependent variable, $\mu=$ Overall adjusted mean, $T_{i}=$ Fixed effect of treatments, $i=1$, 2...7. $\mathrm{e}_{\mathrm{ij}}=$ Random error associated to each observation.

\section{RESULTS AND DISCUSSION}

\section{Amino acid contents of canola meal and soya bean meal:}

Amino acid of canola meal and soya bean meal are listed in Table (2). Data shows that $\mathrm{CM}$ had a moderate level of most amino acids but contain a higher levels of methionine and arginine (1.50 and $30.21 \mathrm{mg} / \mathrm{g}$ ) compared to the same amino acids of soya bean meal (1.05 and $25.85 \mathrm{mg} / \mathrm{g}$ ) respectively. The result 
contrary with that obtained by (Khajali and Slominski, 2012) who found that CM has a lower lysine and arginine content than soybean meal, while Newkirk et al. (2003b) and Bonnardeaux (2011) reported that CM containing high amount of sulfur amino acid. Prepress solvent extracted canola meal is characterized with lower and less consistent amino acid digestibility in broilers than soybean meal (Newkirk et al., 2003b; and NRC 1994). Some amino acids, especially lysine can be turned to biologically unavailable lysine derivatives (un-reactive lysine) during heat processing as well as prolonged storage of feedstuffs (Kim and Mullan, 2012 and Kim et al., 2012).

\section{Egg production:}

Table (3) showed the effects of canola meal (CM), clay and their interactions on egg production of Lohman laying hens. Hens fed diet containing 10 and $15 \% \mathrm{CM}$ recorded the highest $(\mathrm{p} \leq 0.05)$ final body weight and body weight change (1674.37, $1646.83 \mathrm{~g}$ and $144.20,119.17 \mathrm{~g}$ ), respectively. Final body weight and body weight changewere not significantly affected by clay. Interaction between CM and clay had a significant effect on final body weight and body weight change.Hens feed $20 \% \mathrm{CM}$ with or without $2 \%$ clay recorded the lowest significant final body weight and body weight change $(1589.00,1593.33$ and $69.33,74.00 \mathrm{~g})$, respectively. The results are in full agreement with that by Lee et al. (1991), Idrees (1998) and Naseem et al. (2006) who reported that canola meal can be used from 15 to $25 \%$ without any negative influence on growth of broiler chickens chicks. However, Franzon et al. (1998) reported that weight gain in broiler chickens was reduced with a higher canola meal level (30 to $40 \%$ ). Also, El- Sheikh (2016) found that hens fed diet containing $15 \% \mathrm{CM}$ with $1 \mathrm{~g}$ microbial phytase / $\mathrm{kg}$ diet recorded the highest $(p \leq 0.05)$ final body weight and body weight change.

The highest $(\mathrm{p} \leq 0.05)$ egg production $(80.34 \%)$ and egg mass (45.74 g/hen/day) recorded by hens fed diet containing $15 \% \mathrm{CM}$ compared to those fed $20 \% \mathrm{CM}(77.32 \%$ and $45.12 \mathrm{~g} / \mathrm{hen} /$ day). While, hen feed $10 \% \mathrm{CM}$ recorded the highest value of egg weight $(62.44 \mathrm{~g})$. Results obtained Contrary with Perez-Maldonado and Barram (2004), Ciurescu (2009) and Janječić et al. (2009), who found that egg production, egg weight and body weights were not significantly affected when soybean meal was partially replaced with canola meal in layer diet. Egg production, egg weight and egg mass were not significantly affected by clay supplement (Table 3). Kermanshahi et al (2011) reported that egg production and egg weight did not significantly affected by increasing dietary clay level $(0.0,1.5$ and 3.0\%). While, Jin Soo Kim et al. (2011) concluded that increasing dietary clay level $(0.0,0.2$ and $0.4 \%)$, improves the egg production. The interaction between CM level and clay supplementshow that, hen feed $15 \% \mathrm{CM}$ with $2 \%$ clay recorded the highest egg production and egg mas $(81.54 \%$ and $46.72 \mathrm{~g} / \mathrm{hen} /$ day $)$. However group feed $10 \% \mathrm{CM}$ without clay recorded the highest egg weight $(62.97 \mathrm{~g})$ followed by group feed $15 \% \mathrm{CM}$ with $2 \%$ clay supplement (58.16 g). El- Sheikh (2016) found that hens fed diet containing $15 \% \mathrm{CM}$ with $1 \mathrm{~g}$ microbial phytase $/ \mathrm{kg}$ diet recorded the highest $(\mathrm{p} \leq 0.05)$ egg production and egg mass.

Hens fed diet containing 10\% CM recorded the lower $(\mathrm{p} \leq 0.05)$ feed intake $(105.5$ $\mathrm{g} /$ hen/day) followed by hens feed $15 \% \mathrm{CM}$ (107.6 g/hen/day). The best feed conversion ratio was recorded by hen feed $15 \% \mathrm{CM}(2.72$ $\mathrm{g}$ feed/g egg). However feed intake and feed conversion ratio were not significantly effect by clay supplement (Table 3). Kermanshahi et 


\section{Canola meal-Egg quality-Digestion coefficients- Blood characteristics -Clay.}

al. (2011) reported that feed consumption did not significantly affected by increasing dietary clay level $(0.0,1.5$ and $3 \%$ clay diets). Also, Jin Soo Kim et al. (2011) reported that supplementation of clay on laying hen (0.0, 0.2 and $0.4 \%$ ) had no significant effect on feed intake. Regarding to the interaction between CM level and clay, hens fed 20\% CM without clay recorded the highest feed consumption value (111.6 g/hen/day). While, group fed control recorded the best feed conversion (2.39 $\mathrm{g} \mathrm{feed} / \mathrm{g}$ egg) followed by group fed $15 \%$ with $2 \%$ clay $(2.61 \mathrm{~g}$ feed $/ \mathrm{g} \mathrm{egg})$. The finding supported by Gawecki et al. (1986), Franzon et al. (1998) and Trappett (2001), observed that fed layers chicken on diets containing CM level up 20 to $40 \%$ had a better FCR values. However Rojas et al. (1985), Leeson et al. (1987) and Naseem et al. (2006) found that feed intake decreased when canola meal was used up to $15 \%$. El- Sheikh (2016) found that hens fed diet containing $15 \%$ CM recorded the lower amount of feed intake and the best feed conversion compared with those supplied with 10 and 20\% CM. It seem in fact that improved egg production as a result feeding canola meal along with infeed clay may be due to clay had ability to uptake tannins intake, allowing dietary ingredients to be digested and utilized more efficiently especially simple sugars, amino acids and minerals.

\section{Egg quality:}

Results in table (4) showed that albumen wt., yolk wt. \%, shell wt. \%., shape index, shell thickness, Haugh unit and color yolk were not significantly affected by CM levels. Hen fed on diet containing $10 \% \mathrm{CM}$ level recorded the higher yolk index value (49.67\%). Gheisari and Ghayor (2014) feeding laying hen on rapeseed meal up to $20 \%$ did not effects on yolk weight and yolk weight ratio. Riyazi et al. (2009) found that Haugh units did not influenced by $10 \%$ dietary rapeseed meal but increased eggshell weight. Also, Najib and
Al-khteeb (2004) observed significant increase in Haugh units with increasing the proportion of canola seed in diets of layers. All egg quality parameters were not significantly affected by clay supplement except yolk color had effect significantly by clay supplement. These results were agree with Jin Soo Kim et al. (2011) concluded that supplementation of clay level $(0.0,0.2$ and $0.4 \%$ ) had no effect on the egg and shell quality parameters in both experiments. Also, Kermanshahi et al. (2011) shown that shell thickness and the shell percent values did not significantly with increasing clay levels $(0.0$, 1.5 and $3.0 \%$ clay on diets) to the laying diet, respectively. Albumen wt. \%., shell wt. \%, shape index, shell thickness and Haugh unit did not significantly affected by the interaction between $\mathrm{CM}$ level and clay supplement. Hen fed on diet containing $15 \%$ $\mathrm{CM}$ with $2 \%$ clay recorded the highest yolk wt. \% value $(22.01 \%)$. However hen fed $20 \%$ $\mathrm{CM}$ with $2 \%$ clay recorded the lowest value of yolk index (45.99\%) and yolk color (7.80). Also, El- Sheikh (2016) found that hens fed diet containing $15 \% \mathrm{CM}$ recorded the highest $(p \leq 0.05)$ value of albumin weight followed by group fed $20 \%$ CM level. While, hens fed on diet containing 10\% CM recorded the higher $(\mathrm{p} \leq 0.05)$ value of yolk wt. $\%$, shell wt. $\%$, and yolk index.

\section{Digestion coefficients:}

Digestion coefficients of OM, DM, CP, CF, $\mathrm{EE}$ and NFE are summarized in Table (5). Data show that digestibility coefficients values of $\mathrm{OM}, \mathrm{CP}, \mathrm{EE}$ and $\mathrm{NFE}$ were not significantly affected by CM level. While, DM and CFwere significantly influenced by CM levels. Hens fed on 15\% CM recorded the best digestion coefficient of DM (76.78\%) of all other CM levels groups. Hens fed on 20 or $15 \% \mathrm{CM}$ recorded higher values of $\mathrm{CF}$ (38.61 and $37.67 \%$ ) respectively, compared to $10 \%$ CM (33.69\%). Results obtained contrary with Zelenka (2003), Peric et al. (2015) and El- 
Sheikh (2016). All digestion coefficients of $\mathrm{DM}, \mathrm{OM}, \mathrm{CP}, \mathrm{CF}$ and NFE were not significantly affected by clay levels except digestion coefficients of EE was $(p \leq 0.05)$ affected. The interaction between CM level and clay show that digestion coefficient of DM, OM and CP did not influenced. On the other hand, hens fed on diet containing $10 \%$ $\mathrm{CM}$ with $2 \%$ clay recorded the highest value of CF (39.00\%) compared to the other group. while, hens fed on $15 \% \mathrm{CM}$ with $2 \%$ clay recorded the highest values of EE and NFE (91.74 and 83.18\%), respectively.

\section{Some blood serum characteristics:}

Results of Table (6) showed that albumin, globulin, total lipid, creatinine and aspartic transaminase (AST) concentration were not significantly affected by CM levels, but it is noticeable that values increased numerically buy increasing $\mathrm{CM}$ level. However, total protein, urea and Alanine transaminase (ALT) concentration were recorded the higher $(p \leq 0.05)$ values by increasing CM level up to $20 \%$. The finding supported by Ahmed et al. (2015) who found that diets supplemented with $\mathrm{CM}$ at 5,10 and 20\% did not reveal a significant clear effect on serum total protein, albumin and globulin. While, serum creatinine had a higher $(\mathrm{p}<0.05)$

compared to control Szymeczko et al. (2010) reported that using different levels of CM in broiler diet did not affect protein metabolism indices, total protein and albumin but concentration of creatinine was lower in birds fed the diets with the highest level of CM. On the other hand, Pearson et al. (1983) recorded higher plasma total protein and albumin in broilers fed diet supplemented with $500 \mathrm{~g} \mathrm{CM}$ meal $/ \mathrm{kg}$ of broiler diet. The most of blood serum characteristics did not affected by clay level except globulin and ALT has significantly affected. Regarded to the interaction between CM level and clay level noted that total protein, globulin, creatinine and (AST) were not significantly affected by dietary canola meal and clay supplement. While, urea and total lipid concentration were decreased $(\mathrm{p} \leq 0.05)$ in hens fed $10,15,20 \%$ canola levels with $2 \%$ clay supplement, values were $11.83,11.00,11.83$ and $641,758,733 \mathrm{mg}$ $/ \mathrm{dl}$, respectively compared to the control (12.33 and $750 \mathrm{mg} / \mathrm{dl}$ ). Alanine transaminase (ALT) was increased significantly in hen fed $20 \%$ without or with $2 \%$ clay ( 41.00 and 39.33 I.U.L.). While, ALT was decreased ( $\mathrm{p} \leq 0.05)$ in hens fed 10 and $15 \% \mathrm{CM}$ with $2 \%$ clay (24.33 and 25.00 I.U.L.) compared to the control (25.33 I.U.L.). Ahmed et al. (2015) found that CM at a level of 5,10 and 20\% with enzyme supplementation decreased serum AST compared to the control. While, the level 5\% showed lower serum ALT than the control.

\section{Economic efficiency:}

Results in Table (7) show that the best value for economic efficiency and relative economic efficiency had been recorded by hens fed on diet containing $15 \%$ canola meal with $2 \%$ clay ( 0.49 and $140 \%)$ followed by hens fed $10 \% \mathrm{CM}$ without clay (0.40 and $114 \%)$ compared to the control (0.35 and $100 \%$ ). Nascimento et al. (1998) reported that average diet cost decreased with increasing dietary canola meal and also found the largest gross margin (US \$ / head) with 30\% canola meal in diet. Also, El-Sheikh (2016) found that hen fed on diet containing $15 \%$ canola meal with $1 \mathrm{~g}$ microbial phytase / $\mathrm{kg}$ diet recorded the best economic efficiency and relative economic efficiency.

From the nutritional and economic efficiency stand points of view it could be concluded that $15 \% \mathrm{CM}$ with $2 \%$ clay improved significantly egg production, egg mass, egg quality, blood characteristics, economic efficiency and relative economic efficiency. 
Table (1): Percentage composition, Chemical analysis and calculated analysis of the experimental diets

\begin{tabular}{|c|c|c|c|c|c|c|c|}
\hline \multirow[t]{2}{*}{ Ingredients (\%) } & \multirow[t]{2}{*}{ control } & \multicolumn{6}{|c|}{ experimental diet } \\
\hline & & 1 & 2 & 3 & 4 & 5 & 6 \\
\hline Yellow corn & 60.50 & 58.70 & 56.70 & 58.00 & 55.9 & 57.40 & 55.20 \\
\hline Soybean $(44) \%$ & 22.00 & 14.00 & 11.40 & 9.50 & 7.30 & 4.80 & 2.40 \\
\hline Corn gluten $(60) \%$ & 5.20 & 5.00 & 7.10 & 5.20 & 7.00 & 5.50 & 7.60 \\
\hline Canola meal & - & 10.00 & 10.00 & 15.00 & 15.00 & 20.00 & 20.00 \\
\hline Plant oil & 1.00 & 1.00 & 1.50 & 1.00 & 1.50 & 1.00 & 1.50 \\
\hline Clay & - & - & 2.00 & - & 2.00 & - & 2.00 \\
\hline L-Lysine $\mathrm{HCl}$ & 0.10 & 0.10 & 0.10 & 0.10 & 0.10 & 0.10 & 0.10 \\
\hline DL-Methionine & 0.10 & 0.10 & 0.10 & 0.10 & 0.10 & 0.10 & 0.10 \\
\hline Dicalcium phosphate & 1.70 & 1.70 & 1.70 & 1.70 & 1.70 & 1.70 & 1.70 \\
\hline Limestone & 8.90 & 8.90 & 8.90 & 8.90 & 8.90 & 8.90 & 8.90 \\
\hline Premix $* *$ & 0.25 & 0.25 & 0.25 & 0.25 & 0.25 & 0.25 & 0.25 \\
\hline Salt $(\mathrm{NaCl})$ & 0.25 & 0.25 & 0.25 & 0.25 & 0.25 & 0.25 & 0.25 \\
\hline Total & 100 & 100 & 100 & 100 & 100 & 100 & 100 \\
\hline \multicolumn{8}{|c|}{ Chemical analysis: } \\
\hline CP\% & 18.05 & 18.05 & 18.04 & 18.03 & 18.01 & 18.00 & 18.06 \\
\hline CF\% & 3.81 & 3.61 & 3.79 & 3.14 & 3.97 & 3.19 & 3.45 \\
\hline EE\% & 4.87 & 4.78 & 4.23 & 4.63 & 5.91 & 5.89 & 5.83 \\
\hline \multicolumn{8}{|c|}{ Calculated analysis: $* * *$} \\
\hline ME(Kcal/kg) & 2807 & 2803 & 2801 & 2803 & 2804 & 2809 & 2807 \\
\hline $\mathrm{Ca} \%$ & 3.58 & 3.56 & 3.51 & 3.54 & 3.57 & 3.56 & 3.57 \\
\hline Total P\% & 0.66 & 0.61 & 0.66 & 0.57 & 0.67 & 0.54 & 0.67 \\
\hline Available P\% & 0.44 & 0.42 & 0.41 & 0.40 & 0.40 & 0.39 & 0.38 \\
\hline Lysine \% & 0.88 & 0.85 & 0.77 & 0.78 & 0.73 & 0.73 & 0.86 \\
\hline Methionine\&Cysteine\% & 0.60 & 0.58 & 0.53 & 0.55 & 0.51 & 0.53 & 0.49 \\
\hline Methionine\% & 0.42 & 0.37 & 0.38 & 0.34 & 0.35 & 0.31 & 0.33 \\
\hline Price L.E/ton & 2837 & 2581 & 2670 & 2505 & 2540 & 2352 & 2439 \\
\hline
\end{tabular}

$*$ The price of one $\mathrm{kg}$ Canola meal $(\mathrm{CM})=1 \mathrm{~L} . \mathrm{E}$.

** Vit. and Min. Premix contents per Kg of diet: Vit. A, 12000 IU; Vit. D3, 2000 IU; Vit. E, 10 mg; Riboflavin, $4 \mathrm{mg}$; Pantothenic acid, $10 \mathrm{mg}$; Vit. B $12,0.01 \mathrm{mg}$; Choline chloride, $500 \mathrm{mg}$; Vit. K, $2 \mathrm{mg}$; Vit. $\mathrm{B}_{1}, 1 \mathrm{mg}$; Vit. B $61.5 \mathrm{mg}$; Folic acid, $1 \mathrm{mg}$; Niacin, $20 \mathrm{mg}$; Biotin, $0.05 \mathrm{mg}$; Cu, $10 \mathrm{mg}$; I, $1 \mathrm{mg}$; Fe, $30 \mathrm{mg}$; Mn, $55 \mathrm{mg}$; Zn, $55 \mathrm{mg}$; and Se, $0.1 \mathrm{mg}$.

*** According to Tables of NRC (1994). 
Table (2): Amino acids components of canola meal compared to Soya bean meal

\begin{tabular}{|c|c|c|c|c|c|c|c|c|c|c|c|c|c|c|c|c|c|}
\hline \multirow[b]{2}{*}{ Items } & \multicolumn{17}{|c|}{ Amino acids (mg/g) } \\
\hline & 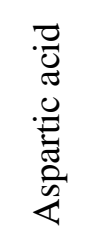 & 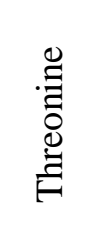 & : & 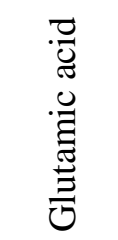 & 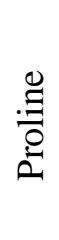 & $\frac{\mathscr{E}}{\stackrel{\Xi}{0}}$ & $\begin{array}{l}\stackrel{0}{\Xi} \\
\text { 芯 } \\
\end{array}$ & $\stackrel{\stackrel{\mathscr{\Xi}}{\leftrightarrows}}{\stackrel{\Xi}{>}}$ & 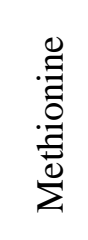 & 苞 & $\begin{array}{l}\stackrel{0}{\Xi} \\
\stackrel{0}{0} \\
\frac{0}{0} \\
0 \\
0\end{array}$ & 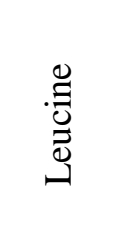 & 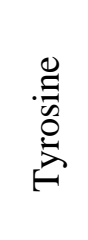 & 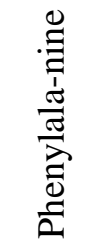 & 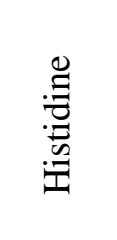 & 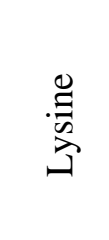 & 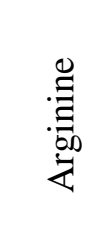 \\
\hline $\begin{array}{l}\text { Canola } \\
\text { meal }\end{array}$ & $\begin{array}{c}25.1 \\
0\end{array}$ & $\begin{array}{c}11.4 \\
7\end{array}$ & $\begin{array}{c}11.3 \\
4\end{array}$ & 56.00 & - & $\begin{array}{c}10.7 \\
8\end{array}$ & $\begin{array}{c}11.2 \\
1\end{array}$ & 12.63 & 1.51 & $\begin{array}{c}3.6 \\
1\end{array}$ & 9.62 & 14.41 & 4.95 & 7.75 & 6.60 & 9.11 & 30.21 \\
\hline $\begin{array}{l}\text { Soya } \\
\text { bean } \\
\text { meal }\end{array}$ & $\begin{array}{c}41.1 \\
9\end{array}$ & $\begin{array}{c}11.0 \\
0\end{array}$ & $\begin{array}{c}17.7 \\
7\end{array}$ & 68.91 & - & $\begin{array}{c}15.5 \\
2\end{array}$ & $\begin{array}{c}17.2 \\
5\end{array}$ & 18.19 & 1.05 & - & $\begin{array}{c}16.3 \\
8\end{array}$ & 27.94 & 7.71 & $\begin{array}{c}17.5 \\
2\end{array}$ & 10.73 & 23.03 & 25.85 \\
\hline
\end{tabular}


Table (3): Egg production of Lohman laying hens as affected by canola meal (CM), clay level and experimental treatments

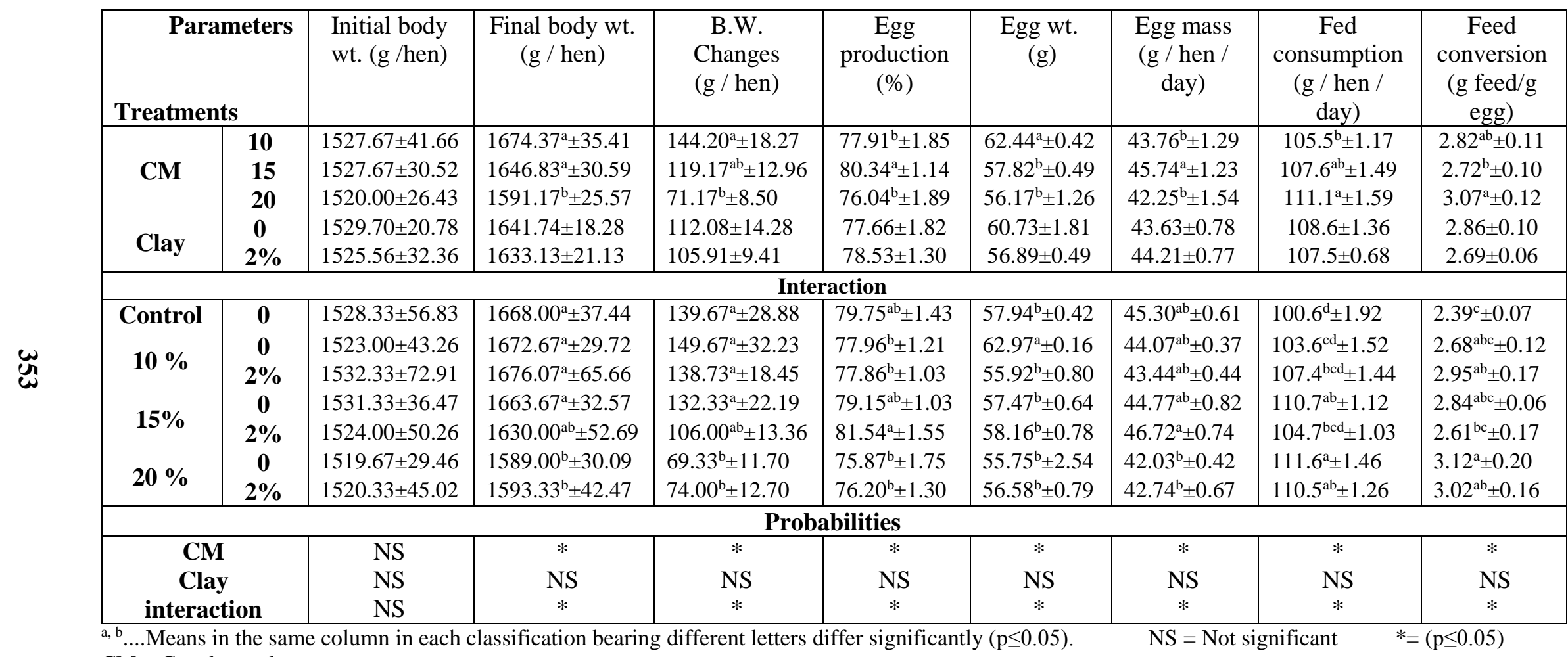

$\mathrm{CM}=$ Canola meal 
Table (4): Egg quality of Lohman laying hens as affected by canola meal (CM), clay level and experimental treatments

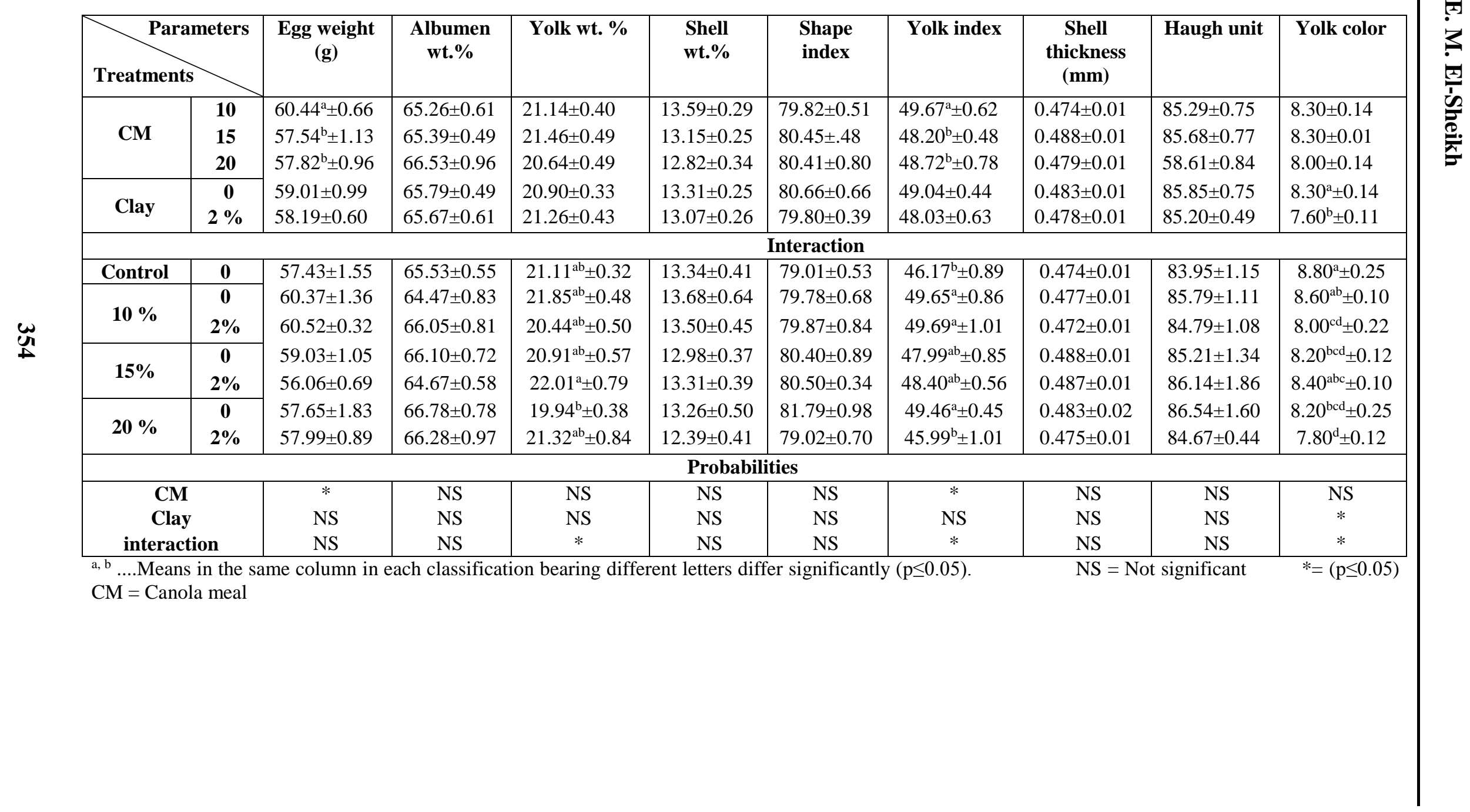


Table (5): Digestion coefficients of experimental diets as affected by canola meal (CM), clay levels and the experimental treatments

\begin{tabular}{|c|c|c|c|c|c|c|c|}
\hline Treatme & neter & DM\% & ОМ\% & СР\% & CF\% & EE\% & NFE\% \\
\hline & 10 & $72.77^{b} \pm 1.10$ & $78.23 \pm 0.98$ & $89.74 \pm 0.42$ & $33.69^{\mathrm{b}} \pm 1.32$ & $85.61 \pm 1.54$ & $76.22 \pm 1.39$ \\
\hline CM & 15 & $76.78^{\mathrm{a}} \pm 0.95$ & $80.88 \pm 1.25$ & $90.62 \pm 0.47$ & $37.67^{\mathrm{a}} \pm 1.08$ & $83.78 \pm 1.85$ & $80.12 \pm 1.58$ \\
\hline & 20 & $72.95^{\mathrm{b}} \pm 1.20$ & $78.60 \pm 1.18$ & $90.09 \pm 0.46$ & $38.61^{\mathrm{a}} \pm 0.77$ & $86.49 \pm 0.85$ & $77.05 \pm 1.80$ \\
\hline & $\mathbf{0}$ & $74.53 \pm 1.00$ & $79.71 \pm 0.95$ & $90.31 \pm 0.35$ & $37.13 \pm 1.07$ & $85.78^{b} \pm 0.99$ & $78.31 \pm 1.16$ \\
\hline clay & $2 \%$ & $75.07 \pm 1.84$ & $79.72 \pm 1.50$ & $89.16 \pm 0.90$ & $37.22 \pm 1.53$ & $88.97^{\mathrm{a}} \pm 1.26$ & $78.29 \pm 1.12$ \\
\hline & & & & Interaction & & & \\
\hline Control & $\mathbf{0}$ & $71.39 \pm 2.11$ & $78.76 \pm 1.82$ & $88.00 \pm 0.52$ & $31.13^{\mathrm{b}} \pm 4.39$ & $85.82^{\mathrm{ab}} \pm 2.33$ & $78.59^{\mathrm{ab}} \pm 2.57$ \\
\hline $10 \%$ & $\mathbf{0}$ & $72.55 \pm 1.70$ & $77.83 \pm 1.56$ & $89.82 \pm 0.55$ & $33.82^{\mathrm{ab}} \pm 1.12$ & $86.06^{\mathrm{ab}} \pm 1.16$ & $75.63^{\mathrm{ab}} \pm 2.07$ \\
\hline $10 \%$ & $2 \%$ & $75.38 \pm 0.56$ & $79.87 \pm 0.94$ & $89.05 \pm 0.57$ & $39.00^{\mathrm{a}} \pm 1.56$ & $87.33^{\mathrm{ab}} \pm 2.42$ & $78.59^{\mathrm{ab}} \pm 1.64$ \\
\hline & $\mathbf{0}$ & $77.27 \pm 1.69$ & $81.63 \pm 2.17$ & $90.27 \pm 0.91$ & $36.36^{\mathrm{ab}} \pm 1.61$ & $84.47^{b} \pm 2.77$ & $81.13^{\mathrm{ab}} \pm 2.62$ \\
\hline $15 \%$ & $2 \%$ & $71.74 \pm 1.23$ & $77.54 \pm 1.22$ & $90.16 \pm 0.31$ & $37.27^{\mathrm{ab}} \pm 2.01$ & $87.83^{\mathrm{ab}} \pm 1.71$ & $72.72^{\mathrm{b}} \pm 1.98$ \\
\hline & $\mathbf{0}$ & $73.78 \pm 0.58$ & $79.67 \pm 0.17$ & $89.82 \pm 0.16$ & $38.59^{\mathrm{ab}} \pm 1.63$ & $86.82^{\mathrm{ab}} \pm 1.14$ & $78.18^{\mathrm{ab}} \pm 0.55$ \\
\hline $20 \%$ & $2 \%$ & $78.09 \pm 2.38$ & $82.36 \pm 2.36$ & $88.25 \pm 1.90$ & $35.39^{\mathrm{ab}} \pm 1.75$ & $91.74^{\mathrm{a}} \pm 2.14$ & $83.18^{\mathrm{a}} \pm 2.42$ \\
\hline & & & & Probabilitie & & & \\
\hline $\mathrm{CN}$ & & * & NS & NS & $*$ & NS & NS \\
\hline Cla & & NS & NS & NS & NS & $*$ & NS \\
\hline Intera & & NS & NS & NS & * & $*$ & * \\
\hline
\end{tabular}

$a, b$....Means in the same column in each classification bearing different letters differ significantly $(\mathrm{p} \leq 0.05)$.

NS $=$ Not significant $\quad *=(\mathrm{p} \leq 0.05) \quad \mathrm{CM}=$ Canola meal 
Table (6): Some blood characteristics (Mean \pm SE) of Lohman laying hens as affected by the experimental treatment

\begin{tabular}{|c|c|c|c|c|c|c|c|c|c|}
\hline \multicolumn{2}{|c|}{ Treatments } & $\begin{array}{c}\text { Total } \\
\text { protein } \\
(\mathrm{g} / \mathrm{dl})\end{array}$ & $\begin{array}{c}\text { Albumin } \\
(\mathrm{g} / \mathrm{dl})\end{array}$ & $\begin{array}{c}\text { Globulin } \\
\text { (g/dl) }\end{array}$ & $\begin{array}{c}\text { Urea } \\
(\mathbf{m g} / \mathrm{dl})\end{array}$ & $\begin{array}{l}\text { Total } \\
\text { lipid } \\
\text { (mg/dl) }\end{array}$ & $\begin{array}{l}\text { Creatinin } \\
\text { e (mg/dl) }\end{array}$ & $\begin{array}{c}\text { ALT } \\
\text { (I.U./ } \\
\text { L) }\end{array}$ & $\begin{array}{c}\text { AST } \\
(\mathbf{I} . U . / L \\
)\end{array}$ \\
\hline \multirow{3}{*}{ CM } & 10 & $3.68^{b}$ & 2.87 & 0.82 & $12.17^{\mathrm{ab}}$ & 719 & 0.39 & $28.83^{b}$ & 57.33 \\
\hline & 15 & $4.52^{\mathrm{a}}$ & 3.17 & 1.35 & $11.92^{\mathrm{b}}$ & 970 & 0.44 & $29.33^{\mathrm{b}}$ & 63.50 \\
\hline & 20 & $4.04^{\mathrm{a}}$ & 3.05 & 0.99 & $13.42^{\mathrm{a}}$ & 1025 & 0.44 & $40.17^{\mathrm{a}}$ & 64.83 \\
\hline \multirow{2}{*}{ Clay } & $\mathbf{0}$ & 3.86 & 3.19 & $0.67^{b}$ & 12.83 & 988 & 0.44 & $36.00^{\mathrm{a}}$ & 54.11 \\
\hline & $2 \%$ & 4.30 & 2.87 & $1.42^{\mathrm{a}}$ & 12.17 & 869 & 0.41 & $29.56^{\mathrm{b}}$ & 69.67 \\
\hline \multicolumn{10}{|c|}{ Interaction } \\
\hline \multirow{3}{*}{$\begin{array}{c}\text { Contol } \\
10 \%\end{array}$} & 0 & 4.18 & $3.30^{\mathrm{ab}}$ & 0.88 & $12.33^{b}$ & $750^{b}$ & 0.67 & $25.33^{\mathrm{b}}$ & 50.66 \\
\hline & $\mathbf{0}$ & 3.62 & $3.12^{\mathrm{ab}}$ & 0.50 & $12.50^{\mathrm{b}}$ & $941^{\mathrm{ab}}$ & 0.44 & $33.33^{\mathrm{b}}$ & 38.66 \\
\hline & $2 \%$ & 3.74 & $2.61^{\mathrm{b}}$ & 1.11 & $11.83^{\mathrm{b}}$ & $641^{\mathrm{b}}$ & 0.33 & $24.33^{\mathrm{b}}$ & 76.00 \\
\hline \multirow{2}{*}{$15 \%$} & $\mathbf{0}$ & 4.18 & $3.60^{\mathrm{a}}$ & 0.58 & $12.83^{\mathrm{ab}}$ & $1291^{\mathrm{a}}$ & 0.44 & $33.66^{\mathrm{b}}$ & 64.33 \\
\hline & $2 \%$ & 4.85 & $2.74^{\mathrm{b}}$ & 2.11 & $11.00^{\mathrm{b}}$ & $758^{\mathrm{b}}$ & 0.44 & $25.00^{\mathrm{b}}$ & 62.66 \\
\hline \multirow[b]{2}{*}{$20 \%$} & $\mathbf{0}$ & 3.78 & $2.85^{\mathrm{b}}$ & 0.93 & $15.00^{\mathrm{a}}$ & $1208^{\mathrm{a}}$ & 0.44 & $41.00^{\mathrm{a}}$ & 59.33 \\
\hline & $2 \%$ & 4.29 & $3.25^{\mathrm{ab}}$ & 1.04 & $11.83^{\mathrm{b}}$ & $733^{\mathrm{b}}$ & 0.44 & $39.33^{\mathrm{a}}$ & 70.33 \\
\hline \multicolumn{10}{|c|}{ Probabilities } \\
\hline & & * & NS & NS & $*$ & NS & NS & * & NS \\
\hline \multirow{2}{*}{\multicolumn{2}{|c|}{$\begin{array}{c}\text { Clay } \\
\text { interaction }\end{array}$}} & NS & NS & $*$ & NS & NS & NS & * & NS \\
\hline & & NS & $*$ & NS & . & * & NS & * & NS \\
\hline
\end{tabular}

${ }^{\mathrm{a}, \mathrm{b}}$ Means bearing different superscripts within the same row are significantly different $(\mathrm{p}<0.05)$.

ALT, alanine transaminase; AST, aspartic transaminase 
Table (7): Economical efficiency of Lohman laying hens as affected by the experimental treatments

\begin{tabular}{|l|c|c|c|c|c|c|c|}
\hline \multirow{2}{*}{\multicolumn{1}{c|}{ Parameter }} & \multirow{2}{*}{ Control } & \multicolumn{6}{|c|}{ Canola meal level \% } \\
\cline { 3 - 8 } & & \multicolumn{2}{|c|}{$\mathbf{1 0}$} & \multicolumn{2}{c|}{$\mathbf{1 5}$} & \multicolumn{2}{c|}{$\mathbf{2 0}$} \\
\cline { 3 - 8 } & & $\mathbf{0 \%}$ & $\mathbf{2 \%}$ & $\mathbf{0 \%}$ & $\mathbf{2 \%}$ & $\mathbf{0 \%}$ & $\mathbf{2 \%}$ \\
\hline Price /kg feed (L.E.) & 2.837 & 2.581 & 2.670 & 2.505 & 2.540 & 2.352 & 2.439 \\
Total feed intake/hen (kg) & 8.450 & 8.702 & 9.022 & 9.299 & 8.795 & 9.374 & 9.282 \\
Total feed cost / hen (L.E.) & 23.97 & 22.45 & 24.09 & 23.29 & 22.34 & 22.05 & 22.64 \\
Egg mass (kg/ hen) & 3.805 & 3.701 & 3.648 & 3.760 & 3.924 & 3.530 & 3.567 \\
Total revenue (L.E.) & 32.34 & 31.46 & 31.01 & 31.96 & 33.35 & 30.01 & 30.32 \\
Net revenue (L.E.) & 8.37 & 9.01 & 6.92 & 8.67 & 11.01 & 7.96 & 7.68 \\
Economicefficiency(Ec.E.) & 0.35 & 0.40 & 0.29 & 0.37 & 0.49 & 0.36 & 0.34 \\
RelativeEc.E.(\%) & 100 & 114 & 83 & 106 & 140 & 103 & 97 \\
\hline
\end{tabular}

$\mathrm{CM}=$ Canola meal

1- Price of clay 1.5 L.E.

2- The price of one $\mathrm{kg}$ egg $=8.5 \mathrm{~L}$.E.

3- Net revenue per unit of total feed cost

4- Relative economic efficiency \% of the control, assuming that relative Ec. E. of the control $=100$. 


\section{REFERENCES}

A.O.A.C., 1990. Official Methods of Analysis. $15^{\text {th }}$ Edition. Association of official Chemists, Washington, USA.

Abou-Raya, A. K.; and Galal, Gh., 1971. Evaluation of poultry feeds in digestion trials with references to some factors involved. U. A. R., Anim. Prod., 11: 207221.

Afsan, K.; Shiga, R.; Isiuzuka, S.; and Hara, H., 2003. Ingestion of an indigestible saccharide, difructose anhydride 111 , partially prevents the tannic acid induced suppression of nonabsorption in rats. J. Nutri., 133: 35533560.

Ahmed, H. A.; Reham, Abou-Elkhair; Sara, A. Ketkat; and Shaimaa, Selim, 2015. Growth and Economic Performance of Broiler Chickens Fed on Graded Levels of Canola Meal with or without Multi-Enzyme Supplementation. J. Agri. Sci.; 7 (6): 137-149.

Bonnardeaux, J., 2011. Uses for canola meal. Department of agriculture and food, Western Australia. 2007. http://www.agric.wa.gov.au/objtwr/ imported_assets/content/sust/biofuel/usesf orcanolameal_report.pdf.

Ciurescu, G., 2009. Efficiency of soybean meal replacement by rapeseed meal and/or canola seeds in commercial layer diets. Archiva Zootechnica, 12(1): 27-33.

Duncan, D. B., 1955. Multiple range and multiple F- test. Biometerics, 11: 1-42.

Eisen, E. J.; Bohren, B. B.; and Mckean, H. E., 1962. The haugh unit as a measure of egg albumen quality. Poult. Sci., 41: 14611468.

El-Sheikh, S. E. M., 2016. Utilization improvement of canola meal as an untraditional feed stuff in laying hen diets. Egypt. Poult. Sci., 36(4): 1117-1130.
Franzon, E. E.; Siewerdi, F.; Ruiz, F.; Brum, P. A.; DE, R.; and Gomes, P. C., 1998. Performance of broilers fed different levels of canola meal. Ciencia Rural, 28(4): 638-689.Poult. Abst. 27(6): 2483.

Frutos, P.; Hervás, G.; Giráldez, F. J.; and Mantecón, A. R., 2004. Tannins and ruminant nutrition, Review. Spanish J. Agric. Res., 2(2): 191-202.

Funk, E. M.; Froning, G.; Grottes, G.; Forward, R.; and Kinder, J., 1985. Quality of eggs laid by caged layers. Worlds Poult. Sci. J., 14: 207.

Gawecki, K., Rutkkowski, A.; and Lipinska, H., 1986. Oil meal from low glucosinolate rapeseed start ' 00 ' to replace soybean meal in diets of broilers. Poult. Abst., 12(11): 2671.

Gheisari, A.; and Ghayor, P., 2014. Different Dietary Levels of rapeseed Meal Effects on Egg Quality Characteristics in Indigenous Breeding Hens. J. Farm Anim. Nutri. Physiol. 9/1 (1): 1 -8.

Idrees, Z., 1998. Effect of different levels of canola meal in diet of broilers, as a substitute of soybean meal. M Sc. Thesis, Department of Animal Nutrition, University of Agriculture, Faisalabad, Pakistan. p. 71.

Jakobsen, P. E.; Kirsten, S. G.; and Nielson, S. H., 1960. Digestibility trials with poultry. Bertningfraforogslaboratoriet, Udgivet of Stants. Kobenhavn, 32, 56: 1.

Janječić, Z.; Mužic, S.; Pintar, J.; Bedeković, D.; Voća, N.; and Šnajder, N., 2009. Rape seed oil-cake in layers nutrition. Krmiva, 5: 295-300.

Jin, Soo Kim, Jong, K. J.; Se, young Ku Yun Y.; Kyung, K.; and Byung, J. C., 2011. Effects of Kaolin (Natural Ligneous Clay) Supplementation on Performance 
and Egg Quality in Laying Hens. J. Anim. Sci. Technol. 53(2): 133-138.

Johnston, K.; Sharp, P.; Chfford, M.; and Morgan, L., 2005. Dietary polyphenols decrease glucose uptake by human intestinal Caco-2 cells FBES letters. 579: 1653-1657.

Kermanshahi, H.; Haji, Agha Jani E.; Hashemipour, H.; and Pilevar, M., 2011. Efficacy of natural zeolite and pigments on yolk color and performance of laying hens. Afric. J. Biotechnol., 10(16): 3237-3242.

Khajali, F.; and Slominski, B. A., 2012. Factors that affect the nutritive value of canola meal for poultry. A review. Poult. Sci., 91: 2564-2575.

Kim, J. C.; Mullan, B. P.; and Pluske, J. R., 2012. Prediction of apparent, standardized, and true ileal digestible total and reactive lysine contents in heat-damaged soybean meal samples. J. Anim. Sci., 90(4): 137-9.

Kim, J. C.; and Mullan, B. P., 2012. Quantification of the variability in the amino acid and reactive lysine content of soybean meal and development of A NIR calibration for rapid prediction of reactive lysine content. South Perth, WA6151: Livestock Industries Innovation, Department of Agriculture and Food, 3 Baron-Hay Court;

Kim, H. S.; and Miller, D. D., 2005. Prolinerich protein moderate the inhibitory effect of tea on iron absorption in rats. J. Nutri., 135: 532-537.

King, D.; Fian, M. Z.; Ejita, G.; Asem, E. K., and Adeola, O., 2000. The effect of tannins on nutrient utilization in the white pekin duck. Br. Poult. Sci., 41:630- 639.

Lee, K.; Olomu, J. M.; and Sim, J. S., 1991. Live performance, carcass yield, protein and energy retention of broiler chickens fed canola and flax full-fat seeds and the restored mixtures of meal and oil. Can. J. Anim. Sci., 71: 897-903.
Leeson, S.; Atteh, J. O.; and Summers, J. D., 1987. The replacement value of canola meal for soybean meal in poultry diets. Can. J. Anim. Sci., 67: 151-158.

Najib, H.; and Al-Khateeb, S. A., 2004. The effect of incorporating different levels of locally produced canola seeds (Brassica napus) in the diet of laying hen. Int. J. Poult. Sci., 3(7): 490-496.

Nascimento, A. H. D.; Gomes, P. C.; Rostagno, H. S.; Albino, L. F. T.; Gomes, M. F. M.; and Runho, R. C., 1998. Use of canola meal in diets for broiler chickens. Revista Brasileira de Zootechnica, 27 6): 1168-1176, Poult. Abst. 25(6): 1791.

Naseem, M. Z.; Khan, S. H., and Yousaf, M., 2006. Effect of feeding various levels of canola meal on the performance of broiler chicks. J. Anim. Sci.; 16: 3-4.

National Research Council (NRC), 1994. Nutrient Requirements of Poultry. $9^{\text {th }}$ rev. ed. Nat 1. Acad. Press. Washington.

Newkirk, R. W.; Classen, H. L.; Scott, T. A.; and Edney, M. J., 2003a. The digestibility and content of amino acids in toasted and non-toasted canola meals. Can. J. Anim. Sci., 83:131-139.

Newkirk, R. W.; Classen, H. L.; and Edney, M. J., 2003b. Effect of prepress-solvent extraction on the nutritional value of canola meal for broiler chickens. Anim. Feed Sci. Technol., 1047: 111-119.

Pearson, A. W.; Greenwood, N. M.; Butler, E. J.; and Fenwick, G. R., 1983. Biochemical Changes in layer and broiler chickens when fed on a high-glucosinolate rapeseed meal. Br. Poult. Sci., 24: 417-427.

Pellet, P. L.; and Young, V. R., 1980. "Nutritional evaluation of protein foods." Published by the United Nation University.

Perez-Maldonado, R. A.; and Barram, K. M., 2004. Evaluation of Australian canola meal for production and egg quality in two 
layer strains. Proceedings of Australian Poultry Science Symposium, 17: 197-198.

Perić, L.; Ivković, M.; Žikić, D.; and Jajić, I., 2015. Effect of rapeseed meal on nutrient digestibility and gut morphology in broiler chickens. Anim. Sci. Biotech., 48(1): $36-39$.

Riyazi, S. R.; Ebrahimnezhad, Y.; Nazeradl, $\quad$ K.; $\quad$ Maheri-Sis, N.; Salamatdust, R.; and Vahdatpour, T., 2009. The effects of replacing soybean meal with different levels of rapeseed meal on egg quality characteristics of commercial laying hens. Asian J. Anim. Vet. Adv., 4: 337-341.

Rojas, E.; Gonzalez, A.; and Tirado, A. J., 1985. Nutritive value of rapeseed oil meal and its effect on performance of broiler chickens and laying hens. Nut. Abst. Rev. (57): 3765 .

Romanoff, A. L.; and Romanoff, A. J., 1949. In (The Avian egg) John Wiley and Sons; Inc., New York, U.S.A.

SAS, 2003. Statistical Analysis System, User's Guide, Statistics, SAS Institute Carry, North Carolina.

Song, J.; Kwon, O.; Chen, S.; Daruwala, R.; Eck, P.; Park, J. B.; and Levne, M., 2002. Flavonoid inhibition of sodium dependent vitamin $\mathrm{C}$ transporter 1 (SVGT1) and glucose transporter isoform 2 (GLUT2) intestinal transporter for vitamin C and glucose. J. Bio. Chem., 277: 15252-15260.
Szymeczko, R.; Topoliński, T.; Burlikowska, K.; Piotrowska, A.; Bogusławska-Tryk, M.; and Blaszyk, J., 2010. Effect of different levels of rape seeds in the diet on performance, blood and bone parameters of broiler chickens. J. Cent. Eur. Agric., 11: 393-400. http://dx.doi.org/10.5513/JCEA01/11.4.84 $\underline{3}$

Thanaseelaan, V.; Niswanathan, K.; Chandrasekaran, D.; Prabakaran, R.; and Chellapandian, M., 2007. Chemical composition, amino acids, minerals and anti-nutritional factors of rapeseed meal. J. Vet. Anim. Sci., 3: 101-105.

Trappett, P., 2001. Low glucosinolate canola meals for laying hens. Cited by W.A. Dudley Cash in Feedstuffs, May 7, p:12.

Zelenka, J., 2003. Effect of pelleting on digestibility and metabolizable energy values of poultry diet. Czech J. Anim. Sci., 48: 239-242. 


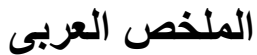 \\ تأثير استخدام كسب الكانولا المعامل بالطمى على أداء الدجاج البياض تحت الظروف الصحراوية سعيد السيا مصطفى الثيخ الثيخ \\ قسم تغذية الحيوان والدواجن ـ مركز بحوث الصحر اء ـ المطرية ـ القاهرة}

استخدم فى هذه الدراسة 105 دجاجة لوهمان بياض عمر 22 اسبوع بهدف دراسة تأثير كسب الكانو لا المعامل بالطمى على الكي

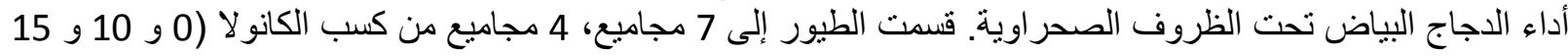
و20\%) ومجمو عتان من الطمى (0 و 2\%) بالإضافة إلى مجمو عة الكنترول. كل مجمو عة بها 5 مكررات بكل مكررة 3 طيور. أهم النتائج المتحصل عليها

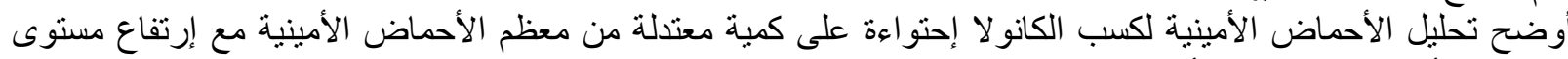

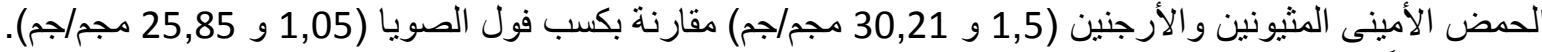

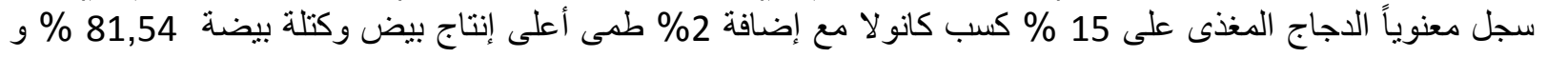

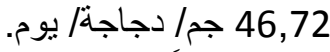

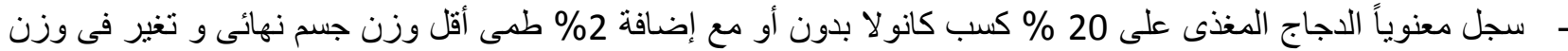

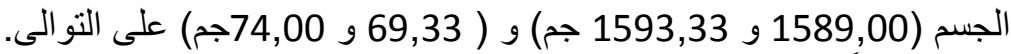

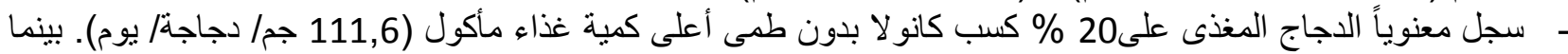

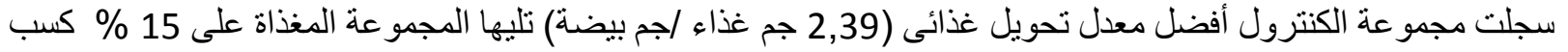

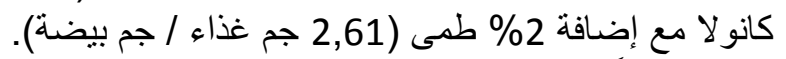

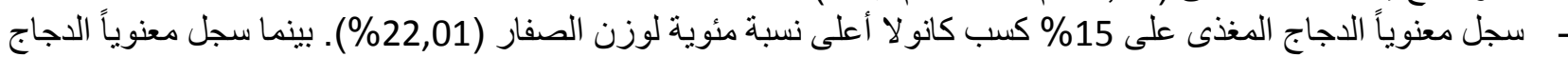

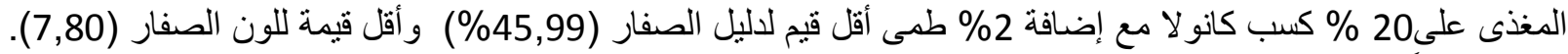

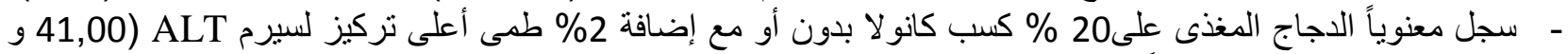
39,33). بينما إنخفض معنوياً فى المجاميع المغذاة على 10 و 15 \% كسب كانو لا مع إضافة الطمى (24,33 و 25 25,00).

خلصت الدراسة إلى أن استخدام 15 \% كسب كانو لا مع إضافة 2\% طمى في على علائق الدجاج البياض حسن معنوياً إنتاج

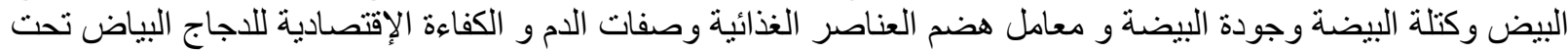

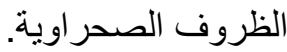

